\title{
A potential role for targeted therapy in a subset of metastasizing adnexal carcinomas
}

\author{
Dora Dias-Santagata ${ }^{1}$, Quynh Lam ${ }^{1}$, Kristin Bergethon ${ }^{1}$, Gabrielle M Baker ${ }^{1}$, A John Iafrate ${ }^{1}$, \\ Dinesh Rakheja ${ }^{2}$ and Mai P Hoang ${ }^{1}$ \\ ${ }^{1}$ Department of Pathology, Massachusetts General Hospital and Harvard Medical School, Boston, MA, USA \\ and ${ }^{2}$ Department of Pathology, University of Texas Southwestern Medical School and Children's Medical \\ Center, Dallas, Texas, USA
}

\begin{abstract}
Metastasizing adnexal carcinomas are rare; thus, currently there is no uniform treatment guideline. Chemotherapeutic drugs that selectively target cancer-promoting pathways may complement conventional therapeutic approaches. We performed immunohistochemistry (epidermal growth factor receptor (EGFR), HER2, and CD117), EGFR and ERBB2 fluorescence in situ hybridization (FISH), and multiplexed SNaPshot $\mathbb{R}$ genotyping (testing for recurrent mutations in 15 cancer genes including BRAF, EGFR, KRAS, PIK3CA, and TP53) on primary tumors and corresponding metastases of 14 metastasizing adnexal carcinomas (three apocrine, six eccrine, two hidradenocarcinomas, two porocarcinomas, and one aggressive digital papillary adenocarcinoma). Metastasis to regional lymph node was most common, followed by skin and then lungs. Follow-up was available in 12 patients (5 months to 8 years) with 1 died of widespread metastases. Although EGFR overexpression was a prevalent feature in this cohort, seen in $7 / 11(64 \%)$ primary tumors and $10 / 14(71 \%)$ metastases; FISH for EGFR gene amplification was negative in 9 tested primary tumors and 12 metastases. FISH of the one primary tumor and three metastases with $2+$ HER2 overexpression revealed a low level of ERBB2 gene amplification in one apocrine carcinoma and corresponding metastasis. CD117 expression was seen only in rare cases. PIK3CA $(2 / 12,17 \%)$ and TP53 (3/12, 25\%) mutations were detected in two (one hidradenocarcinoma, one porocarcinoma) and three (one eccrine, one hidradenocarcinoma, and one aggressive digital papillary adenocarcinoma) cases, respectively. The role of EGFR inhibitor therapy in metastasizing adnexal carcinomas with protein overexpression remains unclear. Targeted therapy including PI3K pathway inhibitors might be a potential treatment for rare cases of adnexal carcinomas with metastases. Modern Pathology (2011) 24, 974-982; doi:10.1038/modpathol.2011.48; published online 18 March 2011
\end{abstract}

Keywords: adnexal neoplasm; EGFR; gene mutation; metastasis; PIK3CA; TP53

Adnexal carcinomas are rare and associated with poor prognosis. Currently, there is no uniform guideline concerning their treatment, especially for those with metastases. Wide surgical excision remains the treatment of choice; but treatment success has been documented only in isolated case reports. ${ }^{1-3}$ Three of nine cases of clear cell eccrine carcinomas reported by Wong et $a l^{4}$ developed

Correspondence: Dr MP Hoang, MD, Dermatopathology Unit, Massachusetts General Hospital, 55 Fruit Street, Warren 820, Boston, MA 02114, USA.

E-mail: mhoang@partners.org

The results have been presented in part at the 31st Symposium of the International Society of Dermatopathology, Barcelona, Spain on October 2010.

Received 16 November 2010; revised 3 January 2011; accepted 4 January 2011; published online 18 March 2011 metastases despite local excision, radiation, and chemotherapy.

Targeted therapy may be a potential treatment option in patients whose tumors are characterized by a relevant oncogene mutation. In a growing number of tumor types including breast and colorectal and lung cancer, selective agents that target critical cancer-promoting pathways are now the treatment of choice for those patients carrying the genetic changes recognized by the drugs. ${ }^{4-7}$

ERBB2 (v-erb-b2 erythroblastic leukemia viral oncogene homolog 2) gene amplification and response to trastuzumab were documented in a case of metastasizing hidradenocarcinoma. ${ }^{2}$ Members of the ERBB receptor tyrosine kinase family, including epidermal growth factor receptor (EGFR), HER2, HER3, and HER4, present possible targeted therapeutic options. ${ }^{8}$ The membranous expression of 
these markers has therapeutic implications and second-generation EGFR tyrosine kinase inhibitors such as HKI-272, XL647, and BIBW2992 have dual activity, inhibiting both EGFR and HER2 receptors. ${ }^{9,10}$

Another case of metastasizing clear cell hidradenocarcinoma was reported to be stabilized over 8 months with Sunitinib treatment, an oral multitargeted tyrosine kinase inhibitor. ${ }^{3}$ KIT (CD117) is known to be expressed in normal adnexal tissue. ${ }^{11}$ Moreover, KIT-activating (v-kit Hardy-Zuckerman 4 feline sarcoma viral oncogene homolog) mutations are reported to be associated with a variety of malignant neoplasms and specific chemotherapeutic agents (imatinib and sorafenib) are available. ${ }^{12,13}$ Clinical experience in patients with gastrointestinal stromal tumor indicates that the presence and location of specific KIT mutations can predict sensitivity and resistance patterns to KIT kinase inhibitors. $^{14}$

To investigate whether metastasizing adnexal carcinomas possess activation of oncogenic pathways that can be targeted by available chemotherapeutic agent, we performed immunohistochemistry for EGFR, HER2, and CD117 (KIT) expression; fluorescence in situ hybridization (FISH) for EGFR and ERBB2 gene amplification; and molecular analyses for recurrent mutations in 15 cancer genes including BRAF, EGFR, KRAS, PIK3CA, and TP53 on cases of adnexal carcinomas with metastases. ${ }^{15}$

\section{Materials and methods}

The study has been approved by the Massachusetts General Hospital institutional review board (IRB No. 2009P001738). Archival materials of all metastasizing adnexal carcinomas including aggressive digital papillary adenocarcinoma, apocrine carcinomas, eccrine ductal carcinoma, hidradenocarcinoma, and porocarcinoma, diagnosed between 1987 and 2010 were retrieved from the pathology files of the Massachusetts General Hospital, Boston, MA, USA. Age, gender, tumor site, tumor size, and clinical follow-up information (such as local recurrence or metastasis) were extracted from the patients' medical records. All patient data were de-identified. The histological sections of all cases were re-examined and the diagnoses were confirmed.

\section{Immunohistochemistry}

Immunohistochemical studies were performed on 5 - $\mu$ m-thick sections of formalin-fixed, paraffinembedded tissue, using the standard techniques, heat-induced epitope retrieval buffer, and primary antibodies against CD117 (1:200, Dakocytomation, Carpinteria, CA, USA), EGFR (3C6, 1:2, Ventana Medical Systems, Tucson, AZ, USA), and HER2 (4B5, predilute, Ventana Medical Systems). Appropriate positive and negative controls were included.
Evaluation of the membranous EGFR expression was performed using a combined scoring system based on both the staining intensity $(0=$ no staining, $1=$ weak, $2=$ moderate, and $3=$ strong staining) as well as the percentage of positive cells $(0 \%=0$, $<25 \%=1,26-50 \%=2,51-75 \%=3$, and $>75 \%=4$ ), similar to that outlined by Janisson-Dargaud et al. ${ }^{16}$ The sum of these two scores yielded a total score from 0 to $7(1-3=$ weak and $4-7=$ strong).

Overexpression of HER2 was defined as positive membranous staining in $>10 \%$ of the neoplastic cells. Partial and faint, weak or thin, and intense or thick circumferential membrane staining in $>10 \%$ of the tumor cells were scored as $1+$ (negative), $2+$ (equivocal), and $3+$ (positive), respectively. Evaluation of CD117-positive cells were recorded as $<10 \%=$ negative, $\quad 10-50 \%=1+, \quad 51-75 \%=2+$, and $>75 \%=3+.{ }^{17}$

\section{Mutational Analysis and EGFR and ERBB2 FISH}

A SNaPshot® genotyping assay recently developed by our group was performed on primary tumors and corresponding metastases of 14 metastasizing adnexal carcinomas with available archival materials. ${ }^{15}$ This assay consists of multiplexed PCR followed by a single-base extension reaction and uses the commercially available SNaPshot platform (Applied Biosystems). The original tumor genotyping panel described by Dias-Santagata et $a l^{15}$ was expanded to include three additional assays (AKT1.49, testing for the AKT1 E17K mutation; IDH1.394 and IDH1.395, testing for hotspot mutations in IDH1, which affect codon R132). The full panel and tests for common mutations in 15 cancer genes are outlined in Table 1. SNaPshot $\AA$ genotyping was performed using previously described conditions, ${ }^{15}$ and included the following additional primers for AKT1 and IDH1 (PCR: AKT1 exon 3 Forward, 5'-ACGTTGGATGGGTAGAGTGTGCGTGG CTCT-3'; AKT1 exon 3 Reverse, 5'-ACGTTGGATGA GGTGCCATCATTCTTGAGG-3'; IDH1 exon 4 Forward, 5'-ACGTTGGATGGGCTTGTGAGTGGATGGGTA-3', IDH1 exon 4 Reverse 5'-ACGTTGGATGgcaaaatcaca ttattgccaac- $3^{\prime}$. Extension: AKT1.49 extR 5'-CTGACT GACTGACTGACTGACTGACTGACTGACTGACTG ACTGACTGACTGACTGACTGACTGACTGACTGA GCCAGGTCTTGATGTACT-3'IDH1.394 extR 5'-GA CTGACTGGACTGACTGACTGACTGACTGGACTG ACTGACTGAGATCCCCATAAGCATGAC-3', IDH1.395 extR $5^{\prime}$-TGATCCCCATAAGCATGA-3'). EGFR gene copy number was assessed in 9 primary tumors and 12 metastases by FISH as previously published. ${ }^{18}$ $E R B B 2$ gene copy number was also assessed in four cases with HER2 IHC overexpression.

\section{Results}

A total of 14 cases were identified: 3 apocrine carcinomas, 6 eccrine ductal carcinomas, 2 hidradeno- 
Table 1 SNaPshot $\AA$ mutational assays ${ }^{15}$

\begin{tabular}{|c|c|c|c|}
\hline Gene & Amino acid-cDNA residue & Gene & $\begin{array}{l}\text { Amino acid-cDNA } \\
\text { residue }\end{array}$ \\
\hline $\begin{array}{l}\text { v-akt murine thymoma viral oncogene } \\
\text { homolog1 (AKT1) }\end{array}$ & E17-49G & NOTCH1 & L1575-4724T \\
\hline \multirow[t]{4}{*}{ Adenomatous polyposis coli (APC) } & R1114-3340C & & L1601-4802T \\
\hline & Q1338-4012C & Neuroblastoma RAS viral (v-ras) & G12-34G \\
\hline & R1450-4348C & oncogene homolog (NRAS) & G12-35G \\
\hline & T1556fs-4666_4667insA & & G13-37G \\
\hline \multirow[t]{2}{*}{$\begin{array}{l}\text { v-raf murine sarcoma viral oncogene } \\
\text { homolog B1 (BRAF) }\end{array}$} & V600-1798G & & G13-38G \\
\hline & V600-1799T & & Q61-181C \\
\hline \multirow{10}{*}{$\begin{array}{l}\text { Catenin (cadherin-associated protein), } \\
\beta 1,88 \mathrm{kDa} \text { (CTNNB1) }\end{array}$} & D32-94G & & Q61-182A \\
\hline & D32-95A & & Q61-183A \\
\hline & S33-98C & Phosphoinositide-3-kinase, & R88-263G \\
\hline & G34-101G & catalytic, $\alpha$ polypeptide (PIK3CA) & E542-1624G \\
\hline & S37-109T & & E545-1633G \\
\hline & S37-110C & & Q546-1636C \\
\hline & $\mathrm{T} 41-121 \mathrm{~A}$ & & Q546-1637A \\
\hline & $\mathrm{T} 41-122 \mathrm{C}$ & & H1047-3139C \\
\hline & $\mathrm{S} 45-133 \mathrm{~T}$ & & H1047-3140A \\
\hline & S45-134C & & G1049-3145G \\
\hline \multirow[t]{5}{*}{ Epidermal growth factor receptor (EGFR) } & G719-2155G & Phosphatase and tensin homolog & R130-388C \\
\hline & T790-2369C & (PTEN) & $\mathrm{R} 173-517 \mathrm{C}$ \\
\hline & L858-2573T & & R233-697C \\
\hline & E746_A750-2235_2249del & & K267fs-800delA \\
\hline & E746 A750-2235 2250del & Tumor protein 53 (TP53) & R175-524G \\
\hline \multirow[t]{2}{*}{$\begin{array}{l}\text { Isocitrate dehydrogenase } 1 \text { (NADP+), } \\
\text { soluble (IDH1) }\end{array}$} & R132-394C & & G245-733G \\
\hline & R132-395G & & R248-742C \\
\hline Fms-related tyrosine kinase 3 (FLT3) & D835-2503G & & R248-743G \\
\hline Janus kinase 3 (JAK2) & V617-1849G & & R273-817C \\
\hline \multirow{5}{*}{$\begin{array}{l}\text { v-kit Hardy-Zuckerman } 4 \text { teline } \\
\text { sarcoma viral oncogene (KIT) } \\
\text { v-Ki-ras2 Kirsten rat sarcoma } \\
\text { viral oncogene homolog (KRAS) }\end{array}$} & D816-2447A & & R273-818G \\
\hline & G12-34G & & R306-916C \\
\hline & G12-35G & & \\
\hline & G13-37G & & \\
\hline & G13-38G & & \\
\hline
\end{tabular}

carcinomas, 2 porocarcinomas, and 1 aggressive digital papillary adenocarcinoma (Table 2). The age of the patients ranged from 38 to 85 years (median, 68.5 years). The male to female ratio was $6: 1$. The majority of the patients received excision and regional lymph node dissection. Three patients received chemotherapy and one received radiotherapy. One patient received both radiotherapy and chemotherapy. Follow-up was available in 12 patients ranging from 5 months to 8 years (Table 2). Recurrences developed in two patients. Metastasis to regional lymph node is most commonly observed. Widespread metastases were observed in two patients that resulted in death in one patient, 7 years status post diagnosis. Metastases to both lymph node and skin were observed in four cases. Metastases to both lymph node and lung were observed in two cases.

\section{Immunohistochemistry}

Immunohistochemistry was performed on 11 primary tumors and 14 metastases. The immunohistochemical results are summarized in Table 3. Overexpression of EGFR was seen in 7/11 (64\%) primary tumors and 10/14 (71\%) metastases (Figure 1a-c). All cases exhibited strong membranous EGFR expression (Figure 1c). Overexpression of HER2 $(2+)$ was seen in $2 / 11(18 \%)$ apocrine carcinomas and 3/14 (21\%) metastases (from two apocrine carcinomas and one aggressive digital papillary adenocarcinoma) (Figure 1d-f). Weak $(1+)$ CD117 expression was noted in 1/ $9(11 \%)$ primary tumors and 1/14 (7\%) metastases (Figure 1g-i).

\section{Mutational Analysis and FISH}

The molecular results are summarized in Table 3. We have recently developed a multiplexed tumor genotyping clinical assay that uses the SNaPshot platform from Applied Biosystems. ${ }^{15}$ This assay performs well with archived tissue and tests for recurrent mutations in 15 cancer genes, including BRAF, EGFR, KRAS, PIK3CA, and TP53 (Table 1). The genes included in this panel were selected 
Table 2 Summary of clinical information

\begin{tabular}{|c|c|c|c|c|c|c|}
\hline & Age/sex & Site & Treatment & Recurrence & Follow-up & Site of metastases \\
\hline \multicolumn{7}{|c|}{ Apocrine carcinoma } \\
\hline 1 & $38 / \mathrm{M}$ & $\mathrm{L}$ axilla & Excision, axillary LN dissection & NA & NA & $\mathrm{L}$ axillary lymph node \\
\hline 2 & $69 / \mathrm{F}$ & $\mathrm{R}$ vulva & $\begin{array}{l}\text { Radical vulvectomy, bilateral } \\
\text { inguinal LN dissection }\end{array}$ & No & 6 years NED & R groin lymph node \\
\hline 3 & $81 / \mathrm{M}$ & Axilla & $\begin{array}{l}\text { Excision, } \mathrm{R} \text { axillary LN } \\
\text { dissection, radiotherapy }\end{array}$ & Yes & $\begin{array}{l}2 \text { years } 7 \text { months } \\
\text { NED }\end{array}$ & Axillary lymph node \\
\hline \multicolumn{7}{|c|}{ Eccrine carcinoma } \\
\hline 4 & $68 / F$ & $L$ foot & Excision & No & 6 months NED & R groin lymph node \\
\hline 5 & $62 / \mathrm{M}$ & L leg & $\begin{array}{l}\text { Amputation, LN dissection, lung } \\
\text { resection }\end{array}$ & No & 7 years DOD & $\begin{array}{l}\text { Lungs, liver, bilateral } \\
\text { adrenals, thoracic LNs }\end{array}$ \\
\hline 6 & $62 / \mathrm{M}$ & Groin & $\begin{array}{l}\text { Radical excision, bilateral LN } \\
\text { dissection, chemotherapy ( } 5-\mathrm{FU} \text {, } \\
\text { cisplatinum), radiotherapy }\end{array}$ & No & 9 months NED & Skin \\
\hline 7 & $58 / \mathrm{M}$ & L neck & Excision & No & 8 years NED & Lymph node \\
\hline 8 & $80 / \mathrm{M}$ & L clavicular & Excison & Yes & 2 years AWD & $\begin{array}{l}\text { Parotid LN, skin, thoracic } \\
\text { spine, brain, spleen }\end{array}$ \\
\hline 9 & $66 / \mathrm{M}$ & L leg & Excision, LN dissection & No & $\begin{array}{l}1 \text { year } 2 \text { months } \\
\text { NED }\end{array}$ & L inguinal lymph node \\
\hline \multicolumn{7}{|c|}{ Porocarcinoma } \\
\hline 10 & $78 / \mathrm{M}$ & L calf & Excision, L groin LN dissection & No & NA & L inguinal lymph node, skin \\
\hline 11 & $85 / \mathrm{M}$ & $\begin{array}{l}\mathrm{L} \text { anterior } \\
\text { auricular }\end{array}$ & Excision, L neck dissection & No & 11 months NED & Intraparotid lymph nodes \\
\hline \multicolumn{7}{|c|}{ Aggressive papillary adenocarcinoma } \\
\hline 12 & $51 / \mathrm{M}$ & $\begin{array}{l}\mathrm{L} \text { index } \\
\text { finger }\end{array}$ & $\begin{array}{l}\text { Excision, L axillary LN } \\
\text { dissection, L lung resection, } \\
\text { chemotherapy ( } 6 \text { cycles of Cabo/ } \\
\text { Taxol) }\end{array}$ & No & 3 years NED & $\begin{array}{l}\text { L axillary lymph node, } \\
\text { L lingular lung }\end{array}$ \\
\hline \multicolumn{7}{|c|}{ Hidradenocarcinoma } \\
\hline 13 & $81 / \mathrm{M}$ & Groin & Excison, LN dissection & No & 9 months NED & Lymph node, skin \\
\hline 14 & $78 / \mathrm{M}$ & R shoulder & $\begin{array}{l}\text { Excision, } \mathrm{R} \text { axillary LN } \\
\text { dissection }\end{array}$ & No & 5 months AWD & $\mathrm{R}$ axillary lymph node, skin \\
\hline
\end{tabular}

Abbreviations: AWD: alive with disease; DOD: died of disease; F: female; LN: lymph node; M: male; NA: not available; NED: no evidence of disease.

based on their clinical significance and on the availability of therapeutic agents (either FDA-approved or under clinical testing) targeting these cancer pathways. ${ }^{15}$ SNaPshot genotyping identified somatic mutations in $42 \%(n=5)$ of the 12 available paired tumor samples (Table 3). Activating mutations in PIK3CA mutations were detected in one hidradenocarcinoma (c.1624G $>$ A; p.Glu542Lys) and one porocarcinoma (c.1633G $>$ A; p.Glu545Lys) (Figure 2). TP53 mutations were detected in one eccrine (c.743G > A; p.Arg248Gln), one hidradenocarcinoma (c.817C > T; p.Arg273Cys), and one aggressive digital papillary adenocarcinoma (c.818G > A; p.Arg273His) (Figure 2). The PIK3CA tumor mutations were found in two older males of this cohort (Tables 2 and 3), but given the sample size correlative analysis is limited.

FISH for EGFR gene amplification was negative in 9 tested primary tumors and 12 metastases, including 7 primaries and 7 metastases with strong EGFR expression. Low level of ERBB2 gene amplification was seen in one apocrine carcinoma and its corresponding metastasis (Table 3).

\section{Discussion}

Adnexal carcinomas and breast carcinomas are analogous tumors often with similar histology. It is interesting that in this study we detected mutations in PIK3CA and TP53 in a subset of metastasizing adnexal carcinomas, as both of these genes are known to be frequently mutated in breast carcinomas. TP53 mutations have been previously described in adnexal carcinomas (Table 4), but to our knowledge this is the first report of PIK3CA mutations in these tumors, which is a therapeutically relevant finding. There was concordant detection of PIK3CA and TP53 mutations in both the primary tumors and the corresponding metastases from patients with metastasizing adnexal carcinomas with the exception of one case (case 11). One possible explanation is that the metastasis had a distinct primary origin. Alternatively, it is conceivable that the primary tumor was heterogeneous and the component without PIK3CA mutation gave rise to the metastasis. Larger studies will be needed to determine whether loss of an activating PIK3CA 
Table 3 Summary of immunohistochemistry, mutational analysis and fluorescence in situ hybridization

\begin{tabular}{|c|c|c|c|c|c|c|c|c|c|c|}
\hline & \multicolumn{3}{|c|}{ Primary } & \multicolumn{3}{|c|}{ Metastasis } & \multicolumn{2}{|c|}{ Primary } & \multicolumn{2}{|c|}{ Metastasis } \\
\hline & $E G F R$ & HER2 & $C D 117$ & $E G F R$ & HER2 & $C D 117$ & SNaPshot $\AA$ results & EGFR FISH & SNaPshot $\AA$ results & EGFR FISH \\
\hline \multicolumn{11}{|c|}{ Apocrine carcinoma } \\
\hline 1 & NA & NA & NA & 0 & $2+($ FISH -$)$ & 0 & NA & NA & NA & NA \\
\hline 2 & 0 & $2+(\text { FISH }+)^{a}$ & 0 & 0 & $2+(\mathbf{F I S H}+)^{a}$ & 0 & WT & $\begin{array}{l}\text { No } \\
\text { amplification }\end{array}$ & WT & $\begin{array}{l}\text { No } \\
\text { amplification }\end{array}$ \\
\hline 3 & 0 & $2+(\mathrm{NA})$ & NA & 0 & 0 & 0 & NA & $\mathrm{NA}$ & WT & $\begin{array}{l}\text { No } \\
\text { amplification }\end{array}$ \\
\hline \multicolumn{11}{|c|}{ Eccrine carcinoma } \\
\hline 4 & 4 & 0 & 0 & 7 & 0 & 0 & WT & $\begin{array}{l}\text { No } \\
\text { amplification }\end{array}$ & WT & No amplification \\
\hline 5 & 0 & 0 & $1+$ & 0 & 0 & 0 & WT & $\begin{array}{l}\text { No } \\
\text { amplification }\end{array}$ & WT & $\begin{array}{l}\text { No } \\
\text { amplification }\end{array}$ \\
\hline 6 & 6 & 0 & 0 & 5 & 0 & 0 & $\begin{array}{l}\text { TP53 c.743G }>\text { A } \\
\text { (p.Arg248Gln) }\end{array}$ & $\begin{array}{l}\text { No } \\
\text { amplification }\end{array}$ & $\begin{array}{l}\text { TP53 c.743G > A } \\
\text { (p.Arg248Gln) }\end{array}$ & $\begin{array}{l}\text { No } \\
\text { amplification }\end{array}$ \\
\hline 7 & 0 & 0 & 0 & 5 & 0 & 0 & NA & NA & NA & NA \\
\hline 8 & 4 & 0 & 0 & 7 & 0 & 0 & WT & $\begin{array}{l}\text { No } \\
\text { amplification }\end{array}$ & WT & No amplification \\
\hline 9 & 7 & 0 & 0 & 7 & 0 & 0 & WT & $\begin{array}{l}\text { No } \\
\text { amplification }\end{array}$ & WT & $\begin{array}{l}\text { No } \\
\text { amplification }\end{array}$ \\
\hline \multicolumn{11}{|c|}{ Porocarcinoma } \\
\hline 10 & NA & NA & NA & 7 & 0 & 0 & NA & NA & WT & $\begin{array}{l}\text { No } \\
\text { amplification }\end{array}$ \\
\hline 11 & 6 & 0 & 0 & 7 & 0 & 0 & $\begin{array}{l}\text { PIK3CA c.1633G > A } \\
\text { (p.Glu545Lys) }\end{array}$ & $\begin{array}{l}\text { No } \\
\text { amplification }\end{array}$ & WT & $\begin{array}{l}\text { No } \\
\text { amplification }\end{array}$ \\
\hline \multicolumn{11}{|c|}{ Aggressive digital papillary adenocarcinoma } \\
\hline 12 & NA & NA & NA & 4 & $2+($ FISH-) & $1+$ & NA & NA & $\begin{array}{l}\text { TP53 c.818G > A } \\
\text { (p.Arg273His) }\end{array}$ & $\begin{array}{l}\text { No } \\
\text { amplification }\end{array}$ \\
\hline \multicolumn{11}{|c|}{ Hidradenocarcinoma } \\
\hline 13 & 5 & 0 & 0 & 5 & 0 & 0 & $\begin{array}{l}\text { TP53 c.817C }>\mathrm{T} \\
\text { (p.Arg273Cys) }\end{array}$ & $\begin{array}{l}\text { No } \\
\text { amplification }\end{array}$ & $\begin{array}{l}\text { TP53 c.817C > T } \\
\text { (p.Arg273Cys) }\end{array}$ & $\begin{array}{l}\text { No } \\
\text { amplification }\end{array}$ \\
\hline 14 & 6 & 0 & 0 & 6 & 0 & 0 & $\begin{array}{l}\text { PIK3CA c.1624G >A } \\
\text { (p.Glu542Lys) }\end{array}$ & $\begin{array}{l}\text { No } \\
\text { amplification }\end{array}$ & $\begin{array}{l}\text { PIK3CA c.1624G >A } \\
\text { (p.Glu542Lys) }\end{array}$ & $\begin{array}{l}\text { No } \\
\text { amplification }\end{array}$ \\
\hline
\end{tabular}

Abbreviations: WT: wild type; NA: not available.

${ }^{\mathrm{a}}$ The ratio between the ERBB2-specific probe and a control centromere probe in chromosome 17 was 2.2 for the primary tumor and 2.3 for the metastasis (50 nuclei count).

Bold indicates positive FISH results.

mutation during tumor progression and metastasis is a common occurrence. Such a finding would have therapeutic implications for patients with metastatic disease and argue for molecular testing of the metastasis before clinical decision-making.

The phosphatidylinositol 3 kinase (PIK3) signaling pathway is an important regulator of cell growth, proliferation, cell motility, angiogenesis, and survival and it has been shown that PIK3CA (phosphatidylinositol 3-kinase, catalytic, $\alpha$ polypeptide) is the most frequently mutated gene in breast cancer. ${ }^{19,20}$ It is thought that in breast cancer, oncogenic mutations in PIK3CA or low levels of PTEN expression may confer resistance to treatment with trastuzumab, a monoclonal antibody that targets the HER2/NEU receptor. ${ }^{21}$ ERBB2 amplification and PIK3CA mutation were validated as biomarkers for sensitivity to the single-agent PIK3 inhibitor, GDC0941, in breast cancer models. ${ }^{22}$ Other studies have shown that cancers with PIK3CA mutations were sensitive to single-agent PI3K inhibitors and dual PI3K-mammalian target of rapamycin inhibitors. ${ }^{23,24}$

In breast carcinomas, the majority of mutations have been identified in the helical domain (exon 9,
$37 \%$ ) and in the kinase domain (exon 20, 63\%) of PIK3CA. ${ }^{25}$ All mutations were single-based substitutions. ${ }^{25}$ Similarly, we detected two mutations, c.1624G $>$ A:p.Glu542Lys and c.1633G $>$ A: Glu545Lys, in exon 9 of PIK3CA, in one hidradenocarcinoma and one porocarcinoma, respectively. These two mutations are among the three most frequently reported mutations in breast cancer. ${ }^{25}$ Mutations in codon 545 are mutational hotspots reported in ovarian and colorectal carcinomas as well. ${ }^{26,27}$ The clustering of mutations within PIK3CA may prove useful for therapeutic purpose.

Tumor suppressor gene, TP53, located on the short arm of chromosome $17 \mathrm{p} 13$ has been implicated in the regulation of cell growth, DNA repair, and apoptosis. The TP53 gene is frequently $(14-52 \%)$ altered in human breast carcinomas and is the most commonly mutated gene in human tumors. ${ }^{28-30}$ Mutations are usually clustered within the most conserved regions of exons $4,5,7$, and $8 .^{31}$ TP53 mutations have been previously documented in nine cases of adnexal carcinomas (Table 4)..$^{32-35}$ Similar to findings reported by Biernat et al, ${ }^{32}$ we found TP53 mutations within codon 248 of exon 7 

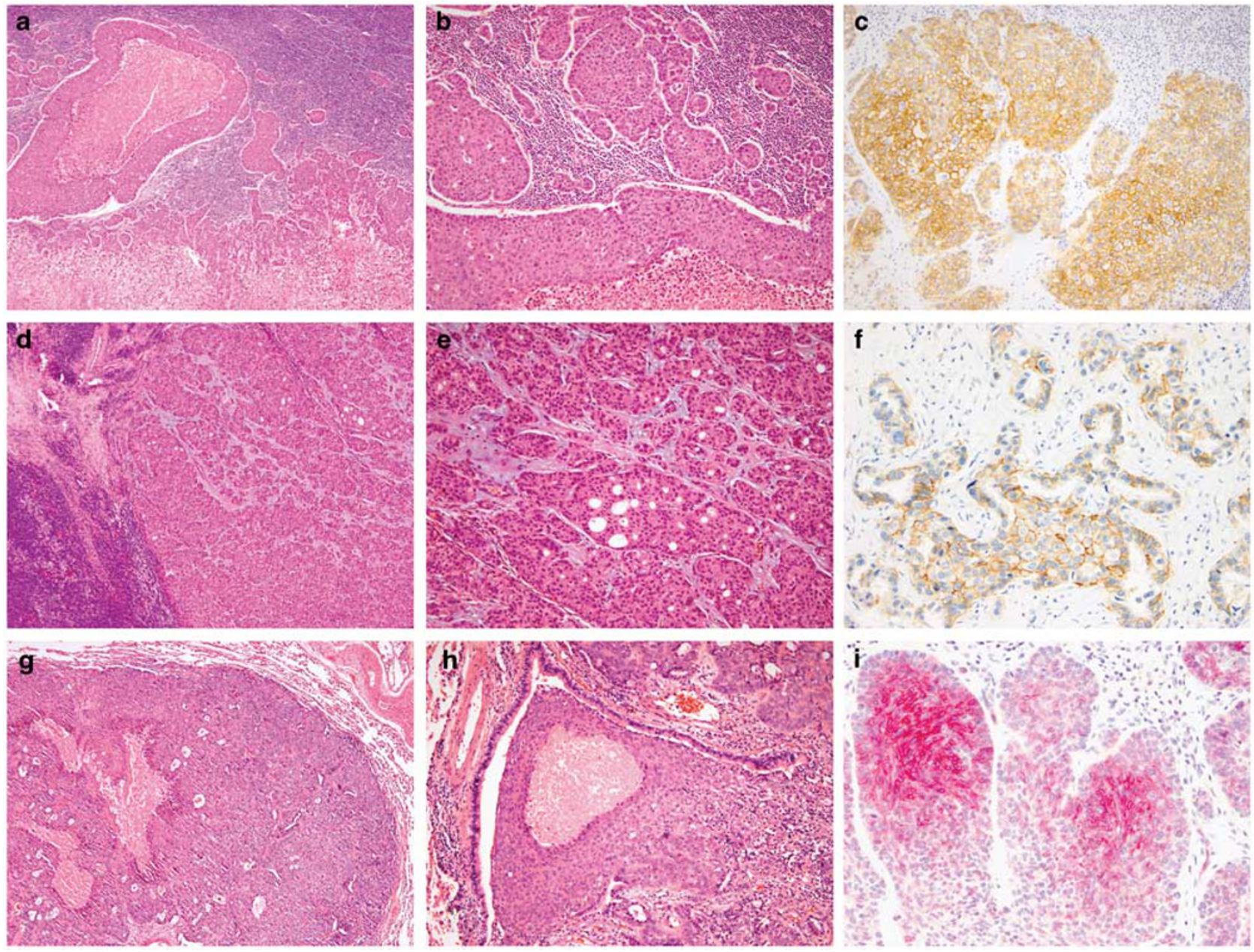

Figure 1 Histologic and immunohistochemical features. (a, b) In a case of metastasizing eccrine carcinoma, nodules and nests of neoplastic cells with comedonecrosis and duct formation are seen within a lymph node $(\times 40, \times 100)$. (c) Strong EGFR membranous staining is seen in the majority of the neoplastic cells $(\times 100)$. (d, e) In a case of metastasizing apocrine carcinoma, there is diffuse replacement of the lymph node by neoplastic cells with ample eosinophilic cytoplasm $(\times 4, \times 100)$. (f) Weak membranous HER2 expression is noted $(\times 200)$. $(\mathbf{g}, \mathbf{h})$ In a case of metastasizing aggressive digital papillary adenocarcinoma, a glandular carcinoma is seen within pulmonary parenchyma. (i) CD117 expression is focally noted $(\times 200)$.

and codon 273 of exon 8 in $25 \%$ of our cases. Interestingly, these mutations have also been reported in breast carcinomas. ${ }^{36-38}$

EGFR/erbB-1 belongs to a receptor family with tyrosine kinase activity whose gene is located on chromosome 7p12. The EGFR signaling that mediates proliferation, migration, invasion, and suppression of apoptosis, can be blocked by a growing number of drug inhibitors. The role of EGFR inhibitor therapy in metastasizing adnexal carcinomas with protein overexpression remains unclear. Although $64 \%$ of the primary tumors and $71 \%$ of the metastases in our series demonstrated EGFR protein overexpression, the EGFR FISH studies were negative. This is not an unexpected finding; as similar results were noted in our recent study of hidradenocarcinomas. ${ }^{39}$ In addition, increased EGFR expression has been shown in various epithelial malignancies with or without gene amplification and the underlying mechanisms of EGFR protein overexpression are still unclear at this time. ${ }^{40}$ The lack of gene amplification does not entirely exclude the role of EGFR inhibitors in the treatment of metastasizing adnexal carcinomas; as there are conflicting results in the literature regarding the role of IHC, FISH, and/or PCR in treatment decision of various tumors. ${ }^{41-43}$ There is frequent discrepancy between the EGFR protein expression and gene amplification in other tumors in the literature. ${ }^{44}$ Furthermore, inconsistent results have also been reported regarding the correlation between EGFR gene mutations and EGFR gene amplification/ polysomy detected by FISH (Bell et al, 2005; Sone et al, 2005). In a recent series of 100 patients with advanced pulmonary adenocarcinoma, Gupta et $a l^{41}$ proposed that tumors should be evaluated by more than one method to identify patients that may benefit from tyrosine kinase inhibitors therapy.

One of three metastasizing adnexal carcinomas in our series with $(2+)$ HER2 overexpression had low 

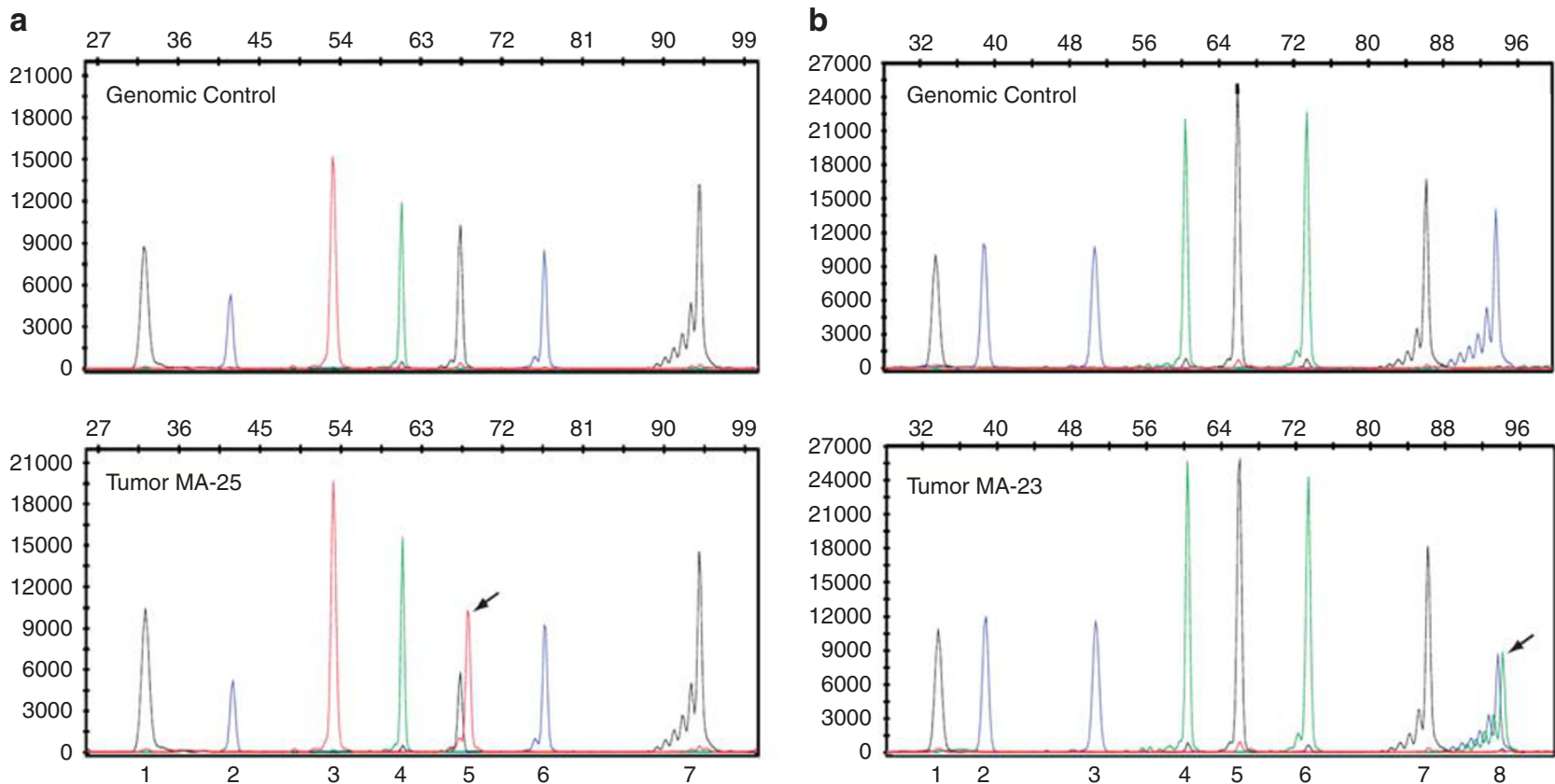

Figure 2 Mutational profiling of metastasizing adnexal carcinoma using SNaPshot $\AA$ genotyping. In both cases, the top panel shows genotyping data obtained with normal male genomic DNA (Promega, Madison, WI, USA) and the lower panel illustrates mutation detection (arrows) in tumor DNA derived from formalin-fixed paraffin-embedded specimens. (a) Identification of the PIK3CA Glu542Lys (c.1624G > A) mutation in case 14 (hidradenocarcinoma) (please note that the PIK3CA 1624 assay is designed in the reverse orientation). Assays: (1) IDH1 395; (2) EGFR 2236_50del F; (3) EGFR 2573; (4) CTNNB1 133; (5) PIK3CA 1624; (6) NRAS 35; and (7) AKT1 49. (b) Identification of the TP53 Arg273His (c.818G > A) mutation in case 12 (aggressive papillary adenocarcinoma). Assays: (1) CTNNB1 98; (2) KRAS 37; (3) EGFR 2155; (4) KIT 2447; (5) PIK3CA 3145; (6) PIK3CA 1637; (7) APC 4012; and (8) TP53 818.

Table 4 Summary of TP53 mutations in adnexal carcinomas ${ }^{32-35}$

\begin{tabular}{|c|c|c|c|}
\hline Case & Histological type & TP53 mutation & Reference \\
\hline 1 & Spiradenocarcinoma & Exon 8, Glu285Lys & Biernat et $a l^{32}$ \\
\hline 2 & Spiradenocarcinoma & Exon 7 , Arg248Gln & Biernat et $a l^{32}$ \\
\hline 3 & Porocarcinoma & Exon 8, codons 273-275, 9 bp deletion & Biernat et $a l^{32}$ \\
\hline 4 & Hidradenocarcinoma & Exon 5, Cys176Tyr & Biernat et $a l^{32}$ \\
\hline 5 & Hidradenocarcinoma & Exon 7, Arg248Gln & Biernat et $a l^{32}$ \\
\hline 6 & Trichilemmal carcinoma & Exon 8 , codon $306, \mathrm{C} \rightarrow \mathrm{T}$ & Takata et $a l^{33}$ \\
\hline 7 & Eccrine carcinoma & Exon 5, Cys176Arg & Takata et $a l^{34}$ \\
\hline 8 & Hidradenocarcinoma & Exon 8, Arg273His & Kazakov et $a l^{35}$ \\
\hline 9 & Hidradenocarcinoma & Exon 6, Arg196X and Arg213X & Kazakov et $a l^{35}$ \\
\hline 10 & Eccrine carcinoma with metastasis & Exon 7, Arg248Gln & Current study \\
\hline 11 & Hidradenocarcinoma with metastasis & Exon 8, Arg273Cys & Current study \\
\hline 12 & Aggressive digital papillary adenocarcinoma with metastasis & Exon 8, Arg273His & Current study \\
\hline
\end{tabular}

level of $E R B B 2$ gene amplification. This is consistent with prior published results indicating that high level ERBB2 gene amplification is unlikely in the setting of $2+$ HER2 overexpression. ${ }^{35}$ Strong $(3+)$ overexpression of HER2 $(3+)$ and gene amplification have been documented in one case of metastasizing malignant hidradenoma. ${ }^{2}$ These findings suggested that ERBB2 may be a relevant therapeutic target in rare cases of adnexal carcinoma.

KIT (CD117) is a transmembrane tyrosine kinase whose alterations are of interest as it is a target for STI571 (Glivec) therapy. In our study, only one case weakly overexpressed CD117. KIT mutational analyses have not been reported in adnexal carcinomas. KIT mutations were found in none of 10 CD117-positive breast carcinomas and in none of 30 adenoid cystic carcinomas of the major and minor salivary glands. ${ }^{45,46}$ These findings suggest that KIT activation may not be a major driving mechanism in adnexal carcinomas and their analogous tumors (breast and salivary gland).

In summary, we report mutations in PIK3CA and TP53 in a subset of metastasizing adnexal carcinomas. The role of EGFR inhibitor therapy in metastasizing adnexal carcinoma cases with protein overexpression remains unclear. The lack 
of correlation between the protein expression and polysomy/gene amplification suggests that molecular mechanisms other than gene amplification have a role in EGFR overexpression in metastasizing adnexal carcinomas. Targeted therapy including PI3K pathway inhibitors, which is currently in clinical testing, might be a potential treatment for rare cases of adnexal carcinomas with metastases. Actual therapeutic trials will be of interest in seeing whether these results will translate to therapeutic response.

\section{Disclosure/conflict of interest}

A patent application for the $\mathrm{SNaPshot} \AA$ genotyping methods used in this study was submitted by DDS and AJI and is currently pending.

\section{References}

1 Schroder U, Dries V, Klussmann JP, et al. Successful adjuvant tamoxifen therapy for estrogen receptorpositive metastasizing sweat gland adenocarcinoma: need for a clinical trial? Ann Otol Rhinol Laryngol 2004;113:242-244.

2 Nash JW, Barrett TL, Kies M, et al. Metastatic hidradenocarcinoma with demonstration of Her-2/ neu gene amplification by fluorescence in situ hybridization: potential treatment implications. J Cutan Pathol 2007;34:49-54.

3 Battistella M, Mateus C, Lassau N, et al. Sunitinib efficacy in the treatment of metastatic skin adnexal carcinomas: report of two patients with hidradenocarcinoma and trichoblastic carcinoma. J Eur Acad Dermatol Venereol 2010;24:199-203.

4 Wong TY, Suster S, Nogita T, et al. Clear cell eccrine carcinomas of the skin: a clinicopathologic study of nine patients. Cancer 1994;73:1631-1643.

5 Cobleigh MA, Vogel CL, Tripathy D, et al. Multinational study of the efficacy and safety of humanized anti-HER2 monoclonal antibody in women who have HER2-overexpressing metastatic breast cancer that has progressed after chemotherapy for metastatic disease. J Clin Oncol 1999;17:2639-2648.

6 Cunningham D, Humblet Y, Siena S, et al. Cetuximab monotherapy and cetuximab plus irinotecan in irinotecan-refractory metastatic colorectal cancer. N Engl J Med 2004;351:337-345.

7 Mok TS, Wu YL, Thongprasert S, et al. Gefitinib or carboplatin-paclitaxel in pulmonary adenocarcinoma. N Engl J Med 2009;361:947-957.

8 Wang SE, Narasanna A, Perez-Torres M, et al. HER2 kinase domain mutation results in constitutive phosphorylation and activation of HER2 and EGFR and resistance to EGFR tyrosinase kinase inhibitors. Cancer Cell 2006;10:25-38.

9 Li D, Ambrogo L, Shimamura T, et al. BIBW2992, an irreversible EGFR/HER2 inhibitor highly effective in preclinical lung cancer models. Oncogene 2008;27: 4702-4711.

10 Riely GJ. Second-generation epidermal growth factor receptor tyrosinase kinase inhibitors in non-small cell lung cancer. J Thorac Oncol 2008;3(Suppl 2): S146-S149.

11 Miettinen M, Lasota J. KIT (CD117): a review on expression in normal and neoplastic tissues, and mutations and their clinicopathologic correlation. Appl Immunohistochem Mol Morphol 2005;13: 205-220.

12 Holden JA, Willmore-Payne C, Layfield LJ. Tyrosine kinase activating mutations in human malignancies: implications for diagnostic pathology. Exp Mol Pathol 2008;85:68-75.

13 Handolias D, Hamilton AL, Salemi R, et al. Clinical responses observed with imatinib or sorafenib in melanoma patients expression mutations in KIT. Br J Cancer 2010;102:1219-1223.

14 Heinrich MC, Corless CL, Blanke CD, et al. Molecular correlates of imatinib resistance in gastrointestinal stromal tumors. J Clin Oncol 2006;24:4764-4774.

15 Dias-Santagata D, Akhavanfard S, David SS, et al. Rapid targeted mutational analysis of human tumors: a clinical platform to guide personalized cancer medicine. EMBO Mol Med 2010;2:146-158.

16 Janisson-Dargaud D, Durlach A, Lorenzato M, et al. Aneuploidy, but not Ki-67 or EGFR expression, is associated with recurrences in basal cell carcinoma. J Cutan Pathol 2008;35:916-921.

17 Torres-Cabala CA, Wang W-L, Trent J, et al. Correlation between KIT expression and KIT mutation in melanoma: a study of 173 cases with emphasis on the acrallentiginous/mucosal type. Mod Pathol 2009;22: 1446-1456.

18 Growdon WB, Boisvert SL, Akhavanfard S, et al. Decreased survival in EGFR gene amplified vulvar carcinoma. Gynecol Oncol 2008;111:289-297.

19 Samuels Y, Ericson K. Oncogenic PI3K and its role in cancer. Curr Opin Oncol 2006;18:77-82.

20 Bachman KE, Argani P, Samuels Y, et al. The PIK3CA gene is mutated with high frequency in human breast cancers. Cancer Biol Ther 2004;3:772-775.

21 Chin L, Gray JW. Translating insights from the cancer genome into clinical practice. Nature 2008;452: $553-563$.

22 Turke AB, Engelman JA. PIKing the right patient. Clin Cancer Res 2010;169:3523-3525.

23 Ihle NT, Lemos Jr R, Wipf P, et al. Mutations in the phophatidylinositol-3-kinase pathway predict for antitumor activity of the inhibitot PX-866 whereas oncogenic Ras is a dominant predictor for resistance. Cancer Res 2009;69:143-150.

24 Serra V, Markman B, Scaltriti M, et al. NVP-BEZ235, a dual PI3K/mTOR inhibitor, prevents PI3K signaling and inhibits the growth of cancer cells with activating PI3K mutations. Cancer Res 2008;68:8022-8030.

25 Michelucci A, Cristofano CD, Lami A, et al. PIK3CA in breast carcinoma: a mutational analysis of sporadic and hereditary cases. Diagn Mol Pathol 2009;18: 200-205.

26 Wang Y, Helland A, Holm R, et al. PIK3CA mutations in advanced ovarian carcinomas. Hum Mutat 2005; $25: 322$.

27 Samuels Y, Wang Z, Bardelli A, et al. High frequency of mutations of the PIK3CA gene in human cancers. Science 2004;304:554.

28 Berns EM, Klijn JG, Smid M, et al. TP53 and myc gene alterations independently predict poor prognosis in breast cancer patients. Genes Chromosomes Cancer 1996;16:170-179. 
29 Elledge RM, Allred DC. The P53 tumor suppressor genes in breast cancer. Breast Cancer Res Treat 1994;32:39-47.

30 Hollstein M, Sidransky D, Vogelstain B, et al. p53 mutations in human cancer. Science 1991;253:49-53.

31 Levine AJ. p53, the cellular gatekeeper for growth and division. Cell 1997;88:323-331.

32 Biernat W, Peraud A, Wozniak L, et al. p53 mutations in sweat gland carcinomas. Int J Cancer 1998;76: 317-320.

33 Takata M, Hashimoto K, Mehregan P, et al. Genetic changes in sweat gland carcinomas. J Cutan Pathol 2000;27:30-35.

34 Takata M, Rehman I, Rees JL. A trichilemmal carcinoma arising from a proliferating trichilemmal cyst: the loss of the wild-type p53 is a critical event in malignant transformation. Hum Pathol 1998;29:193-195.

35 Kazakov DV, Ivan D, Kutzner $\mathrm{H}$, et al. Cutaneous hidradenocarcinoma: a clinicopathological, immunohistochemical, and molecular biologic study of 14 cases, including Her2/neu gene expression/amplification, TP53 gene mutation analysis, and $t(11 ; 19)$ translocation. Am J Dermatopathol 2009;31:236-247.

36 Rapakko K, Allinen M, Syrjakoski K, et al. Germline TP53 alterations in Finish breast cancer families are rare and occur at conserved mutation-prone sites. Br J Cancer 2001;84:116-119.

37 Ruijs MWG, Verhoef S, Rookus MA, et al. TP53 germline mutation testing in 180 families suspected of Li-Fraumeni syndrome: mutation detection rate and relative frequency of cancers in different familial phenotypes. J Med Genet 2010;47:421-428.

38 Kuenen-Boumeester V, Henzen-Logmans SC, Timmermans $\mathrm{MM}$, et al. Altered expression of p53 and its regulated proteins in phyllodes tumours of the breast. J Pathol 1999;189:169-175.

39 Piris A, Scopsi L, Clemente C, et al. Epidermal growth factor receptor gene status by fluorescent in situ hybridization in malignant, atypical, and benign hidradenomas. Am J Dermatopathol 2010;32:586-592.

40 Nicholson RI, Gee JM, Harper ME. EGFR and cancer prognosis. Eur J Cancer 2001;37(Suppl 4):9-15.

41 Gupta R, Dastane AM, Forozan F, et al. Evaluation of EGFR abnormalities in patients with pulmonary adenocarcinoma: the need to test neoplasms with more than one method. Mod Pathol 2009;22:128-133.

42 Bell DW, Lunch TJ, Haserlat SM, et al. Epidermal growth factor receptor mutations and gene amplification in non-small cell lung cancer: molecular analysis of the IDEAL/INTACT gefitinib trials. J Clin Oncol 2005;23:8081-8092.

43 Sone T, Kasahara K, Kimura H, et al. Comparative analysis of epidermal growth factor receptor mutations and gene amplification as predictors of gefitinib efficacy in Japanese patients with nonsmall cell lung cancer. Cancer 2007;109:1836-1844.

44 Kersting C, Tidow N, Schmidt H, et al. Gene dosage PCR and fluorescence in situ hybridization reveal low frequency of EGFR amplifications despite protein overexpression in invasive breast carcinoma. Lab Invest 2004;84:582-587.

45 Simon R, Panussis S, Maurer R, et al. KIT (CD-117)positive breast cancers are infrequent and lack KIT gene mutations. Clin Cancer Res 2004;10:178-183.

46 Holst VA, Marshall CE, Moskaluk CA, et al. KIT protein expression and analysis of c-kit mutation in adenoid cystic carcinoma. Mod Pathol 1999;12: 956-960. 